\title{
English and Russian Somatic Phraseological Units: Differentiating Outcomes
}

\author{
Liliya Mukharlyamova, Assiya Sulkarnayeva
}

\begin{abstract}
This paper deals with the outcomes of a comparative analysis of English and Russian somatic phraseological units, namely the lexical, structural and semantic levels have been involved; the total number of somatic phraseological units is more than 300 units.

Somatic phraseological units (further as PhUs) represent a wide group in any language. The lexical and semantic group of somatic PhUs is regarded an independent subsystem within Phraseology of any language. This system is comprised of PhUs whose key constituent parts include human body part names (from Greek soma means human body or a body part). It should be noted that the most frequent PhUs include somatisms. This circumstance can hardly be explained by interlinguistic reasons only. The somatic components correspond both to sensual (eye) and logic (head) level of knowledge and a criterion of its validity-practice (hand). PhUs with somatisms in their structure appeared in different languages at different time due to the development of the language, culture, social and political contacts of the nation with other nations. However, PhUs with somatisms have some general basis for the use of any human body parts, to express physical and psychological states, feeling and emotions of people. Somatic PhUs belong to a highly-frequent zone of lexical structure, to its oldest, primordial, and socially significant part. As a rule, they are polysemantic words, their separate transferred meaning to a greater or lesser extent are noticeable in phraseological meanings of separate PhUs. Nevertheless, the main, primary and direct meanings (of a body part) play the decisive role in the formation and use of any somatic PhUs.
\end{abstract}

Keywords. Somatic phraseological unit, somatism, comparative analysis, lexical and structural peculiarities, full equivalence, partial equivalence, zero equivalence.

\section{INTRODUCTION}

No doubt that being acquainted with a foreign language, studying and investigating it, a learner or a researcher penetrates into a new national culture, gets involved into great spiritual wealth preserved by a given language. The objective of this paper is to carry out the comparative analysis of the English and Russian somatic nomination represented in the form of somatic phraseological units. To reach this objective the following tasks are set: 1. to make an analysis of the somatic phraseological units of the English and Russian languages and display the peculiarities of their arrangement; 2. to explore their equivalence; 3 . to research semantic and structural (syntactic) relationship inside somatic phraseological units. The topicality is revealed in a complex research to studying the somatic phraseological units of the two heterogeneous languages (English and Russian), which nevertheless reflect the universal specifics inherent to such units. The novelty of the research lies in the comparative analysis of English and Russian somatic PhUs revealing their semantic and structural equivalency.

\section{METHODS OF THE RESEARCH}

The methods applied in present paper are descriptive and comparative; semantic and qualitative analysis, logical systematization as well as overall exception of the material have been involved as well.

The material for this comparative analysis comprises 309 English and Russian somatic phraseological units. The sources for their collection are both monolingual and bilingual phraseological and explanatory dictionaries [7-13-17].

\section{RESULTS}

A comparative analysis of 309 somatic phraseological units in the English and Russian languages has been conducted. The whole corpus includes 24 pairs of somatisms. These somatisms have been excerpted - according to the previous investigation by A.R. Sulkarnayeva (2004) [1] - as the most frequently used in both English and Russian languages. Each pair of somatisms comprises a number of somatic phraseological units. They in their turn have been excerpted with the help of the method of overall excerption out of various most authoritative lexicographic sources (English and Russian phraseological (idiomatic) dictionaries).

We have explored the semantic and structural (syntactic) equivalence of somatic PhUs. Thus, there have been distinguished the following types of phraseological relations: 1) full equivalents, coinciding in semantic and structural-syntactic forms; 2) partial equivalents, partly coinciding either in semantic or in structural-syntactic forms; 3) zero equivalents, having diametrically different semantic meanings, structural-syntactic forms and even other lexical units (words) instead of somatisms. The table below shows the results of the percentage analysis of equivalence types for all 24 pairs. 
English And Russian Somatic Phraseological Units: Differentiating Outcomes

Table. Percentage analysis of equivalence types for somatic PhUs ${ }^{1}$

\begin{tabular}{|c|c|c|c|c|}
\hline No. & PHU with somatic components & Full equivalence in \% & $\begin{array}{c}\text { Partial equivalence } \\
\text { in \% }\end{array}$ & $\begin{array}{c}\text { Zero equivalence in } \\
\text { \% }\end{array}$ \\
\hline 1$)$ & head/голова & 44 & 22 & 34 \\
\hline 2$)$ & hand/ рука & 50 & 40 & 10 \\
\hline 3$)$ & arm/рука & 45 & 55 & 25 \\
\hline 4$)$ & back/спина & 40 & 35 & 35 \\
\hline 5$)$ & face/лицо & 10 & 55 & 55 \\
\hline 6$)$ & finger/палец & 15 & 30 & 50 \\
\hline 7$)$ & foot/ нога (стопа & 25 & 25 & 30 \\
\hline 8$)$ & blood/кровь & 25 & 50 & 60 \\
\hline 9$)$ & тоuth/рот & 0 & 40 & 60 \\
\hline 10$)$ & bone/кость & 10 & 30 & 35 \\
\hline 11$)$ & face/ лицо & 10 & 55 & 60 \\
\hline 12$)$ & brain/мозг & 5 & 35 & 25 \\
\hline 13$)$ & еаr/ухо & 30 & 45 & 55 \\
\hline 14$)$ & еуе/глаз & 25 & 20 & 25 \\
\hline 15$)$ & heart/сердце & 4 & 35 & 35 \\
\hline 16$)$ & lip/губа & 10 & 55 & 10 \\
\hline 17$)$ & leg/нога & 30 & 60 & 33 \\
\hline 18$)$ & песk/шея & 34 & 33 & 20 \\
\hline 19$)$ & nоse/нос & 35 & 45 & 25 \\
\hline 20$)$ & shoulder/плечо & 4 & 35 & 25 \\
\hline 21$)$ & tongue/язык & 40 & 35 & 35 \\
\hline 22$)$ & tooth/зуб & 30 & 35 & 25 \\
\hline 23$)$ & heel/пятка & 40 & 35 & 35 \\
\hline 24$)$ & brain/мозг & 10 & 55 & \\
\hline
\end{tabular}

Briefly, partial equivalence is the most frequent type; zero equivalence is more frequent than full equivalence. Full equivalents demonstrate that somatisms are those unique units which help people express the most difficult notions of extralinguistic reality - both material and spiritual notwithstanding their nationality, culture, social and educational background, religion, geographical location, political views, etc. The differences in their syntactical (structural) organization lead to our next result, that is partial equivalence prevails over other types of equivalence, which is best seen in the table. Partial equivalents may be semantically identical, i.e. their somatic phraseological meaning may coincide in both English and Russian, but structurally they differ from each other. Zero equivalence is that type of equivalence which illustrates the specific, unique and nationally-colored features of Phraseology of each language. This type informs us of specific historical and cultural background of English and Russian-speaking people, their ethnical mentality and original language.

\section{DISCUSSION}

It should be stated that 24 pairs of somatic phraseological units in the English and Russian languages have been enrolled for a comparative analysis. The analysis for all 301 somatic $\mathrm{PhUs}$ is rather extended to be presented in full in this paper. Therefore, the authors will present the analysis for the somatic PhUs including the following somatisms: head, hand, face. These somatisms are the most frequent in any language; they are productive and active in forming numerous somatic $\mathrm{PhUs}$.

1. The English phraseological unit Above/Over someone's head has the meaning of "too difficult for someone to understand". Its Russian equivalent is "выцие чвего-л. понимания". It is clear that they are characterized by a common meaning "a person, a person's position in some affair", they differ only in their evaluative meaning because in the Russian PhU instead of the word "head", the word "понимания" is used. Therefore, we can consider them as absolute semantic equivalents, but structurally, they are partial equivalents. Generally, they are partial structural-semantic phraseological equivalents.

2. The English phraseological unit Get something into one's head has the following meaning: "be convinced about something; believe that something is true etc, usually when it is not true or unlikely." Its Russian equivalent is "вбить в голову". They are differing in their functional-stylistic components ("забрать себе в голову" belongs to the colloquial style). They are partial semantic equivalents. Structurally, they are partial equivalents. We can consider them as partial structural-semantic phraseological equivalents.

3. The English phraseological unit Head and shoulders (above someone) usually has the meaning of "1) much bigger physically. 2) superior in skill, ability or intelligence". Its Russian equivalent is "1) На голову выше, лучше (кого-л) 2) Силой." From semantic point of view, they are absolute equivalents because the Russian equivalent is used in the colloquial way. Structurally, they are also absolute equivalents. Therefore, we can consider them as absolute structural-semantic phraseological equivalents.

4. The English phraseological unit From head to toe (foot) has the meaning of 1) "throughly". 2) "all over one's body". Its Russian equivalent is " $C$ 
головы до пят". From semantic point of view, they are absolute equivalents. Structurally, they are absolute equivalents too. Therefore, we can consider them as absolute structural-semantic phraseological equivalents.

5. The English phraseological unit Lose one's head usually has the meaning of "panic, lose control, and act in a confused way". Its Russian equivalent is "Потерять голову". It is clear that Russian equivalent is absolute to its English one. Structurally, they are absolute equivalents. We can consider them as absolute structural-semantic phraseological equivalents.

6. The English phraseological units Take it into one's head has the meaning of "have a brain wave, someone become very exciting." Its Russian equivalent is "Вбить себе что-либо в голову." It is clear that Russian equivalent is absolute to its English one. Structurally, they are absolute equivalents. Therefore, we can consider them as absolute structural-semantic equivalents.

7. The English phraseological unit Head over heels usually has the meaning of "completely." Its Russian equivalent is "Вверх тормашками." It is clear that from semantic points of view, Russian equivalent has no equivalent to its English one. The Russian one is used in colloquial way. Structurally, they are zero equivalents. We can consider them as zero structural-semantic phraseological equivalents.

8. The English phraseological unit Keep (hold) one's head above water has the meaning of "keep out of debt, out of difficulty." Its Russian equivalent is "удержаться на поверхности". It is clear that from semantic point of view, Russian equivalent is partial to its English one. Structurally, they have no equivalents. We can consider them as zero structural-semantic phraseological equivalents.

9. The English phraseological unit Knock their heads together has the meaning of "People disagree and someone in authority, they force them to reach an agreement." Its Russian equivalent is "привести в чувство." It is clear that Russian equivalent has no equivalent to its English one. The Russian one is used in transferred meaning. Structurally, they have no equivalent too. We can consider them as zero structural-semantic phraseological equivalents. Let us summarize the analysis of somatic PhUs with the component of hеаd/голова and present the percentage of their equivalency.

\section{Diagram 1. Equivalency percentage data for the somatic PhUs with head/zолова}
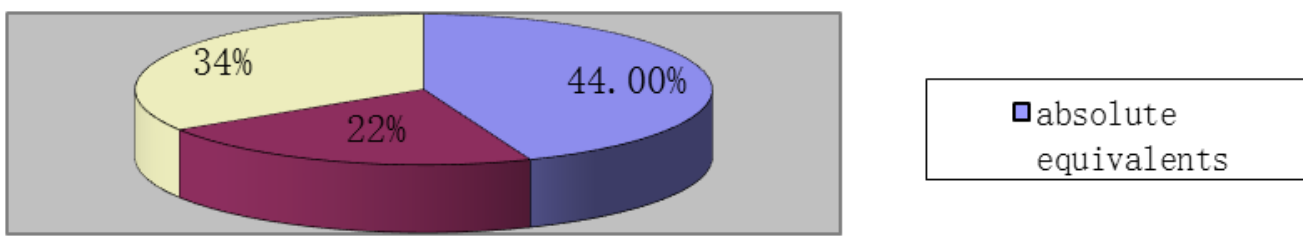

Thus, concluding the analysis we may state that head as a major body part, which is widely used in English and Russian PhUs. No matter the nation or the language is different, head is frequently used in almost the same situations or expresses similar emotions. It is clear that the English and Russian somatic PhUs have absolute equivalents to a considerable degree only, i.e. $44 \%$; zero equivalents comprise $34 \%$ and about $22 \%$ of the English and Russian somatic PhUs are regarded partial equivalents.

1. The English phraseological unit Bind/tie smb. hand and foot usually has the meaning of "be unable/ powerless to act." Its Russian equivalent is "связать кого-л. по рукам и ногам." It is clear that the Russian equivalent is absolute to its English one. They are semantic equivalents. Structurally, they are also absolute equivalents. Therefore, we can consider them as absolute structural-semantic phraseological equivalents.

2. The English phraseological unit Hand in hand usually has the meaning of "1) two things are closely connected and cannot be considered separately from each other; 2) closely together, often with a single aim" Its Russian equivalent is “рука об руку, сообща.” It is clear that Russian equivalent is absolute equivalent to its English one. Structurally, they are absolute equivalents too. Therefore, we can consider them as absolute structural-semantic phraseological equivalents.

3. The English phraseological unit Fall (get) into smb's hands usually has the meaning of "be unable/ powerless to act." Its Russian equivalent is “попасть в чьи-л. руки." It is clear that the Russian equivalent is absolute to its English one. They are semantic equivalents. Structurally, they are also absolute equivalents. Therefore, we can consider them as absolute structural-semantic phraseological equivalents.

4. The English phraseological unit On the one hand... on the other hand has the meaning of "from one side...from another side". Its Russian equivalent is “с одной стороны...другой стороны" It is clear that Russian equivalent is partial to its English one, because in the Russian PhU instead of the word "hand", the word "стороны" is used. Structurally, they are absolute equivalents. Therefore, we can consider them as partial structural-semantic phraseological equivalents.

5. The English PhU Gain /get the upper hand has the meaning of "win an advantage over something/someone, thus gaining a position of power." Its Russian equivalent is “одержать победу." It is clear that Russian equivalent is partial its English one. Structurally, they are partial equivalents. Therefore, we can consider them as partial structural-semantic phraseological equivalents.

6. The English phraseological unit Give/lend someone a hand has the meaning of' help someone physically, e.g. to carry, lift, move something." Their Russian equivalent is "протянуть кому-л. руку помощи. It is clear that a Russian equivalent is absolute to its English one. Structurally, they are also partial equivalents. So we can consider them as partial structural-semantic phraseological equivalents.

7. The English phraseological unit A fresh (or green) hand usually has the meaning of "inexperienced person; unpracticed worker, beginner." Its Russian equivalent is “Неопытный человек; неопытный работник, новичок." It is clear that 
Russian equivalent is absolute to its English one. Structurally, they are zero equivalents. Therefore, we can consider them as partial structural-semantic phraseological equivalents.

8. The English PhU Hand over first has the meaning of "quickly and uncontrollably." Its Russian equivalent is “быстро и легко." It is clear that Russian equivalent is absolute to its English one. Structurally, they are zero equivalents. Therefore, we can consider them as partial structural-semantic phraseological equivalents.
9. The English phraseological unit win someone hands down usually has the meaning of "win very easily with a clear lead." Its Russian equivalent is “выиграть без труда." It is clear that Russian equivalent is absolute equivalent to its English one. Structurally, they are zero equivalents. Therefore, we can consider them as zero structural-semantic phraseological equivalents.

Let us summarize the analysis for the somatic PhUs with the component of hand/кucmb and show their percentage equivalency.

Diagram 2. Equivalency percentage data for the somatic PhUs with hand / кисть

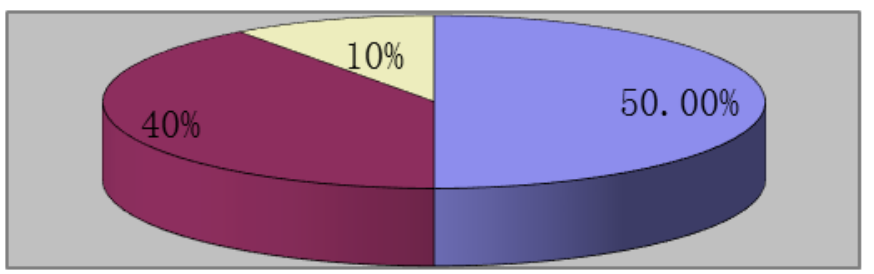

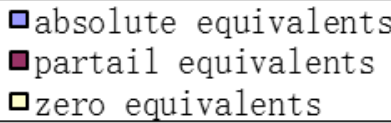

口absolute equivalents

$\square$ partail equivalents

$\boldsymbol{\square}_{\text {zero equivalents }}$

As far as it is seen hand is another major body part, which is most frequently used in our everyday life. People, no matter the race and nationality, cannot live and create anything without the help of hand. Hand is so widely used in somatic PhUs in English and Russian, representing similar actions or expressing similar emotions. It is clear that the English and Russian somatic PhUs have absolute equivalents to a rather considerable degree, namely $50 \%$; zero equivalents are presented in $10 \%$ only; about $40 \%$ of the English and Russian somatic PhUs display partial equivalents.

1. The English PhU Face to face usually has the meaning of "meet criticism, punishment etc. or to deal with an unpleasant situation.” Its Russian equivalent is “ 1 ) друг против друга; 2) лицом к лицу." It is clear that Russian equivalent is absolute to its English one. Structurally, they are also absolute equivalent. Therefore, we can consider them as absolute semantic-structural phraseological equivalents.

2. The English PhU A face as long as a fiddle usually has the meaning of "sad, gloomy face". Its Russian equivalent is "мрачное лицо, вытянутая физиономия." It is clear that Russian equivalent is used in transferred meaning, is partial to its Russian one." Structurally, they are partial equivalents too. Therefore, we can consider them as partial semantic-structural phraseological equivalents.
3. The English PhU Keep a straight face usually has the meaning of "not laugh even though one finds something very funny; hide one's amusement." Its Russian equivalent is “бесстрастное лицо."It is clear that Russian equivalent is partial to its English one. Therefore, we can consider them as partial semantic-structural phraseological equivalents.

4. The English PhU stare someone in the face usually has the meaning of "very obvious or clearly noticeable, but often not noticed by the person concerned." Its Russian equivalent is “1) бросаться кому-л. в глаза, быть очевидным; 2) быть неминуемым" It is clear that Russian equivalent is partial to its English one. Instead of "face", "глаза" is used. Structurally, they are also partial equivalents. Therefore, we can consider them as partial semantic-structural phraseological equivalents.

5. The English phraseological unit Put a bold/brave face on smth usually has the meaning of "hide one's worry by pretending that nothing is wrong, show courage in times of difficulty." Its Russian equivalent is “действовать смело.” It is clear that Russian equivalents are used in transferred meaning, so they have no equivalent to its English one. So, we can consider them as zero semantic-structural phraseological equivalents. Let us summarize the analysis for the somatic PhUs with the component of face/лицо.

\section{Diagram 3. Equivalency percentage data for the somatic PhUs with face/лицо}

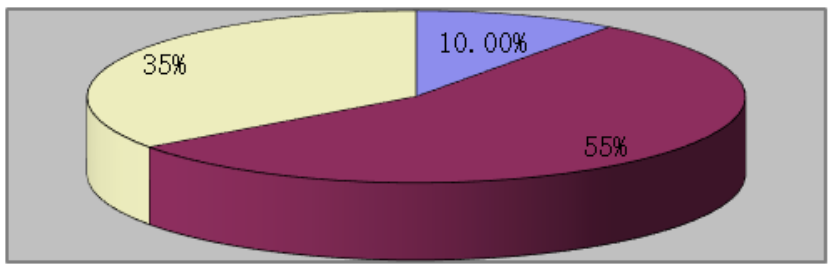

absolute equivalents apartail equivalents $\square_{\text {zero equivalents }}$
Face as one more main body part is always used in our everyday life. It is clear that the English and Russian somatic PhUs have partial equivalents to a considerable degree, i.e. $55 \%$; there are less zero equivalents, i.e. $35 \%$; about $10 \%$ only display absolute equivalents between the English and Russian somatic PhUs. 


\section{CONCLUSION}

This paper has dealt with the research of the English and Russian somatic phraseological units, which in their structure have a word, denoting a part of human body part (hand, leg, heart, etc.) They possess specific peculiarities in the lexical and semantic field and represent as a huge group in the phraseological corpus.

Many scholars - and we do agree with them on the point have determined that in the process of communication, we as a rule refer to the most applicable way of nominating the extralinguistic reality, i.e. using names of a human body parts to express our idea. Thus, it is obvious that Phraseology of every language has been - mostly and very often - formed with the help of somatic phraseological units, which make our language more colourful and specific. As it is well known, somatic phraseological units are an integral part of language, which makes our speech more authentically native. The majority of human body parts and their nomination have several symbolical meanings.

In conclusion, it may be stated that each language comprises a great amount of somatisms in the structure of phraseological units, which to a certain extent correlate with each other - and this is a universal feature, preserving at the same time their own specific characteristics - and this is an idioethnic feature.

\section{ACKNOWLEDGEMENTS}

The work is performed according to the Russian Government Program of Competitive Growth of Kazan Federal University.

\section{REFERENCES}

1. Sulkarnayeva A.R. Otsomaticheskaya vtorichnaya nominatciya v tekhnicheskoy termonologii [in Russian]. - Astana, 2009. - 146 p.

2. Amosova N. Osnovy angliyskoy frazeologii [in Russian]. - Lnd., 1962. $-228 \mathrm{p}$.

3. Gabdrakhmanova, F.H., Mukhametzyanova, L.R., Shayakhmetova, L.Kh. Associative experiment is an effective method of research of the national character (on the material of tatar and Russian liguistic cultures) (2015) Mediterranean Journal of Social Sciences, 6 (3), pp. 296-300.

4. Ayupova R.A., Bashirova M.A., Bezuglova O.A., Kuznetsova A.A., Sakhibullina K.A. Ornythonym component and phraseological meaning. Life Science Journal. 2014, 11(11), pp. 290-293.

5. Vinogradov V.V. Leksikologiya I leksikografiya [in Russian]. M. 1977. - 349 p.

6. Shaiakhmetova L., Shayakhmetova L., Ashrapova A., Zhuravleva Y. Using Songs in Developing Intercultural Competence, 2017, Tarih kultur ve sanat arastirmalari dergisi-journal of history culture and art research, V. 6, pp. 639-646.

7. Jennifer Seidl, W. McMordie. English Idioms and How to Use Them.M.,1993. $-356 \mathrm{c}$.

8. Cowie, A.P. and R. Mackin and I.R. McCaig. Oxford Dictionary of English Idioms. (previously published as Oxford Dictionary of Current idiomatic English Volume 2) - Oxford., 1998.-pp 542.

9. Kunin A.V. Anglo-russkiy frazeologicheskiy slovar. - M.,1967.- 588 p.

10. Smith L. «Words and Idioms» - Lnd. 1998. -pp 465.

11. Webster's New World Dictionary of American English. N.Y.1978.-pp 540.

12. Cowie A. P. and R. Mackin. Oxford Dictionary of Current Idiomatic English.

13. Apresyan Yu.D. Novyi bolshoy Anglo-Russkiy slovar. - M.,1987.- 365 p.

14. Sazesh, A., \& Siadat, S. A. (2018). The Relationship between Quantum Management and Organizational Agility in Ministry of Roads and Urban Development of Golestan Province, Iran. Dutch Journal of $\begin{array}{llll}\text { Finance } \quad \text { and } & \text { Management, }\end{array}$ https://doi.org/10.29333/djfm/5827
15. Guzmán, S. A., Fóster, P. F., Ramírez-Correa, P., Grandón, E. E., \& Alfaro-Perez, J. Information Systems and their Effect on Organizational Performance: An Inquiry into Job Satisfaction and Commitment in Higher Education Institutions. Journal of Information Systems Engineering \& Management, 3(4), (2018). 26.

16. Putri, S. K., Hasratuddin, \& Syahputra, E. Development of Learning Devices Based on Realistic Mathematics Education to Improve Students' Spatial Ability and Motivation. International Electronic Journal of Mathematics Education, 14(2), (2019). 393-400 https://doi.org/10.29333/ieime/5729

17. Sailaukyzy, A., Shakuova, R., Sak, K., \& Lebedeva, T. (2018). Contemporary view to the history of Kazakhstan's democratic journalism and publicism. Opción, 34(85-2), 774-799. 